\title{
Provenance of basinal sandstones in the Upper Jurassic Hareelv Formation, Jameson Land Basin, East Greenland
}

\author{
Mette Olivarius, Morten Bjerager, Nynke Keulen, Christian Knudsen and Thomas F. Kokfelt
}

\begin{abstract}
Zircon U-Pb geochronology and heavy mineral CCSEM analysis were used to interpret the provenance of Oxfordian-Volgian sandstones of the Hareelv Formation in East Greenland. Six samples were collected from the Blokelv- 1 core drilled in southern Jameson Land, and the zircon age distributions and heavy-mineral assemblages are quite uniform. The samples contain a wide spectrum of Archaean to Palaeozoic zircon ages with peak ages at 2.71, 2.49, 1.95, 1.65, 1.49, 1.37, 1.10 and $0.43 \mathrm{Ga}$ when combining all data. The heavy-mineral compositions show derivation from felsic source rocks, some of which were metamorphic. The results reveal that the sediment was derived from the Caledonides, and it is plausible that some or all of the material has experienced several cycles of sedimentation. Devonian and Carboniferous sediments preserved north of the area have zircon age distributions that correspond to those from the Hareelv Formation, and such rocks may have been reworked into the Jameson Land Basin. The provenance signature describes both the gravity-flow sandstones of the Hareelv Formation and the delta-edge sands that are inferred to have fed them. Lithological and provenance contrasts between the sandstones of the Sjællandselv Member and those of the Katedralen Member indicate a shorter transport distance, source to sink, suggestive of proximal topographic rejuvenation in the Volgian.
\end{abstract}

Keywords: East Greenland, Hareelv Formation, Upper Jurassic, sediment provenance, zircon geochronology, heavymineral analysis

Geological Survey of Denmark and Greenland (GEUS), Øster Voldgade 10, DK-1350 Copenhagen, Denmark.

E-mail:mol@geus.dk

The fully cored borehole Blokelv-1 was drilled in 2008 to a depth of $233.8 \mathrm{~m}$ in southern Jameson Land, East Greenland (Fig. 1) to provide reservoir and source-rock information on the mudstone-dominated Upper Jurassic Hareelv Formation that also includes numerous gravityflow sandstones (Bjerager et al. 2018a, this volume). The East Greenland Caledonides, which form the basement for the Mesozoic succession, comprise a complex series of Archaean to Palaeozoic lithologies (Higgins \& Leslie 2008), and therefore the post-Caledonian sedimentary successions preserved along the East and North-East Greenland coast (Fig. 1) are expected to contain a wide range of zircon age populations. Detrital zircon ages from Jurassic sediments in East Greenland have previously only been reported from the Lower Jurassic succession in the Jameson Land Basin where the elevated Liverpool Land High was the primary source area (Slama et al. 2011). Significantly different zircon age distributions are to be expected in the Upper Jurassic sediments in the Jameson Land Basin since the Liverpool Land High was gradually onlapped and drowned during the Middle Jurassic (Surlyk 2003). The present study employs zircon geochronology and heavy-mineral analysis to characterise the Upper Jurassic sandstones of the Hareelv Formation in the Blokelv- 1 core and to identify the source areas of these sandstones. 


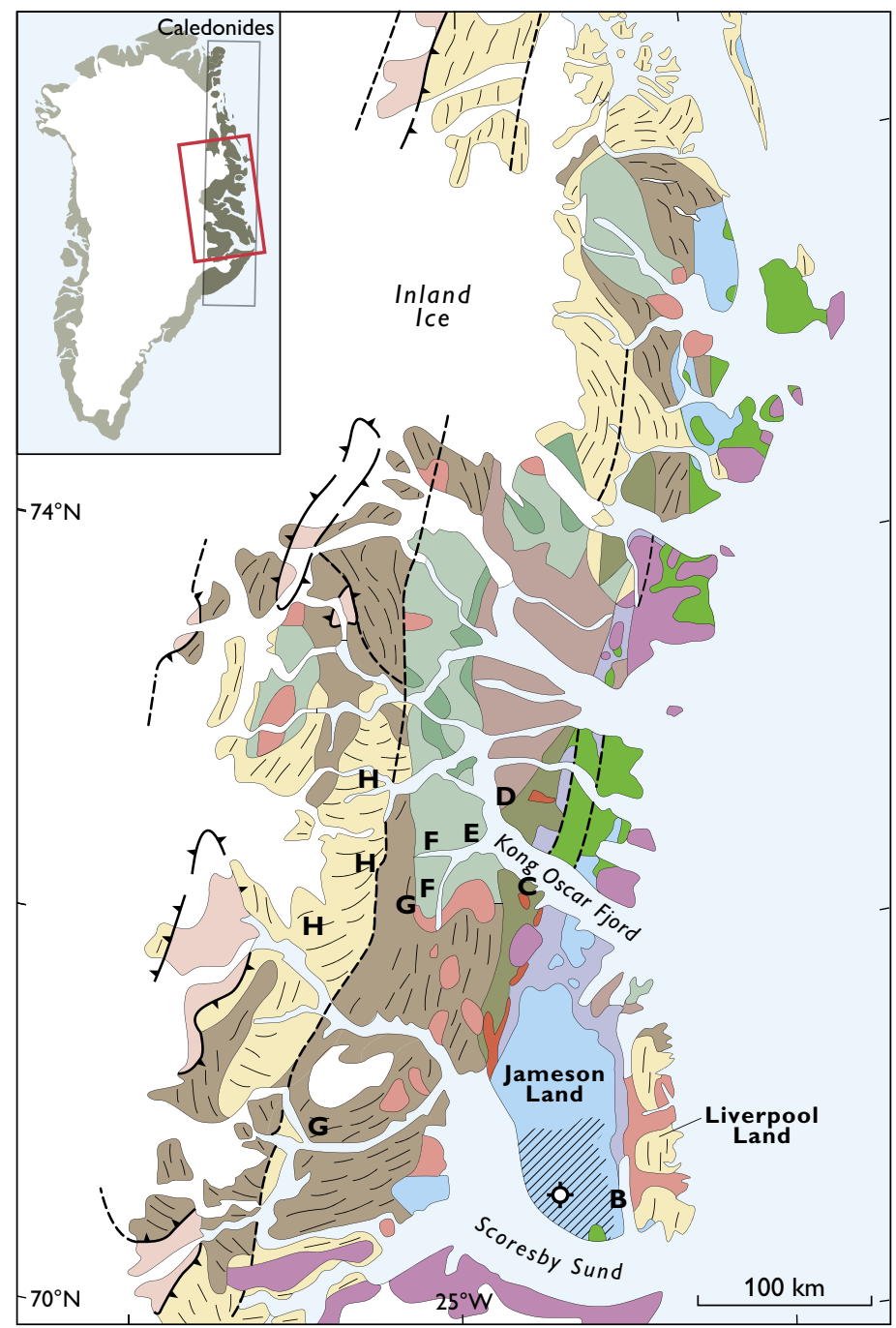

Palaeogene volcanic rocks

Cretaceous

DA Hareelv \& Raukelv Formations

Jurassic

Triassic

Permian

Carboniferous

Devonian continental

Cambrian-Silurian

Neoproterozoic (mainly Eleonore Bay Supergroup)

Neoproterozoic and Caledonian granite

Meso-Neoproterozoic metamorphic rocks

(including Krummedal supracrustal sequence)

i/l Archaean-Palaeoproterozoic crystalline complex

Tectonic windows with crystalline rocks

Thrust

-'Fault/shear zone

-. Blokelv-1 borehole

B-H Localities for zircon age data from literature (see Fig. 7)

Fig. 1. Geological map of the Caledonian belt in East and North-East Greenland based on Stemmerik et al. (1997), Henriksen et al. (2008) and Kalsbeek et al. (2008b). The sampled Blokelv-1 borehole is located in southern Jameson Land. Note that the sediments and metamorphic rocks are categorised by their depositional ages.

\section{Geological setting}

The Caledonian Orogen in East Greenland formed during the Palaeozoic closure of the Iapetus Ocean and continental collision between Baltica and Laurentia (McKerrow et al. 2000). The Caledonian foreland of Laurentia (Greenland) consists mainly of crystalline rocks that are presently exposed in tectonic windows along the rim of the Greenland ice sheet (Fig. 1; Henriksen et al. 2008). The Caledonian Orogen is composed of several westward displaced thrust sheets that consist of Archaean to Silurian crystalline and sedimentary rocks (Higgins et al. 2004). The crystalline complexes in the orogen were formed during Archaean and Palaeoproterozoic times (Thrane 2002). The sediments of the Krummedal supracrustal sequence were deposited in the late Mesoproterozoic to early Neoproterozoic and underwent high-grade metamorphism, migmatisation and partial melting in the early Neoproterozoic (Kalsbeek et al. 2000, 2008a; Watt et al. 2000). A thick sedimentary succession was subsequently deposited in the eastern part of the area which consists of the Neoproterozoic Eleonore Bay Supergroup overlain by the upper Neoproterozoic Tillite Group and the Lower Palaeozoic Kong Oscar Fjord Group (Higgins et al. 2004). This succession and the underlying basement units were partially affected by Caledonian metamorphism. Marine sedimentation was terminated during the uplift caused by the Caledonian crustal thickening, and late- to post-Caledonian continental sediments were deposited during the Devonian after the extensional collapse of the Caledonian Orogen (Larsen et al. 2008). The Caledonian Orogeny caused renewed granite intrusion and migmatisation during the Ordovician-Silurian (Kalsbeek et al. 2001). 
Fig. 2. Stratigraphic scheme of the Upper Jurassic succession in Jameson Land based on Bjerager et al. (2018b, this volume).

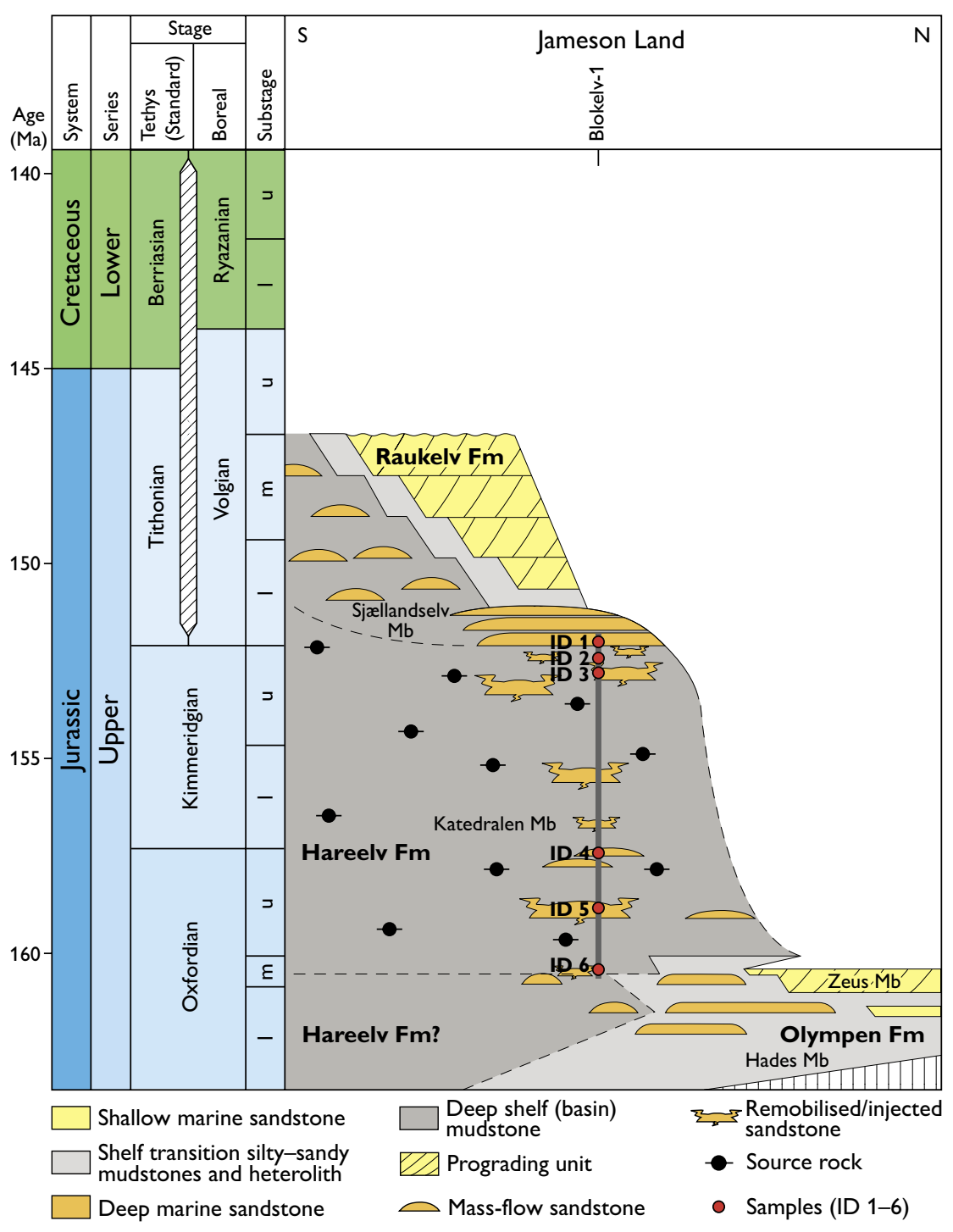

The post-Caledonian sedimentary succession of Carboniferous to Palaeogene age is exposed along the coast of East and North-East Greenland from $70^{\circ}$ to $76^{\circ} \mathrm{N}$ (Fig. 1; e.g. Stemmerik et al. 1992) except where it is overlain by extensive Palaeogene plateau basalts that were extruded in association with the North Atlantic continental breakup (Brooks 2011). Thermal subsidence in the sedimentary basins was succeeded by rifting in the Middle Jurassic and a thick succession was deposited in the Jameson Land Basin until the rifting in the region waned in the earliest Cretaceous (Surlyk 2003).

The Oxfordian Olympen Formation with its marine basinal mudstones and deltaic sandstones is the only part of the Upper Jurassic succession that is preserved in northern Jameson Land (Fig. 2), where it is exposed on the highest mountain peaks (Larsen \& Surlyk 2003).
The orientation of planar cross-bedding in the delta-top deposits in the upper part of the formation (Zeus Member) shows that the delta prograded towards the south. In southern Jameson Land, a near-complete Upper Jurassic succession is exposed and consists of basinal mudstones interbedded with gravity-flow sandstones of the Oxfordian-Kimmeridgian Katedralen Member of the Hareelv Formation (Surlyk 2003). These sandstones were formed by collapse of the drowned shelf-edge delta deposits of the Olympen Formation situated at the northern margin of the Jameson Land Basin (Figs 2, 3) (Bjerager et al. $2018 \mathrm{~b}$, this volume). Some of the gravity-flow sandstones of the Katedralen Member were remobilised and intraformationally injected after burial (Surlyk et al. 2007). The coarser-grained gravity-flow sandstones of the Volgian Sjællandselv Member of the Hareelv Formation 

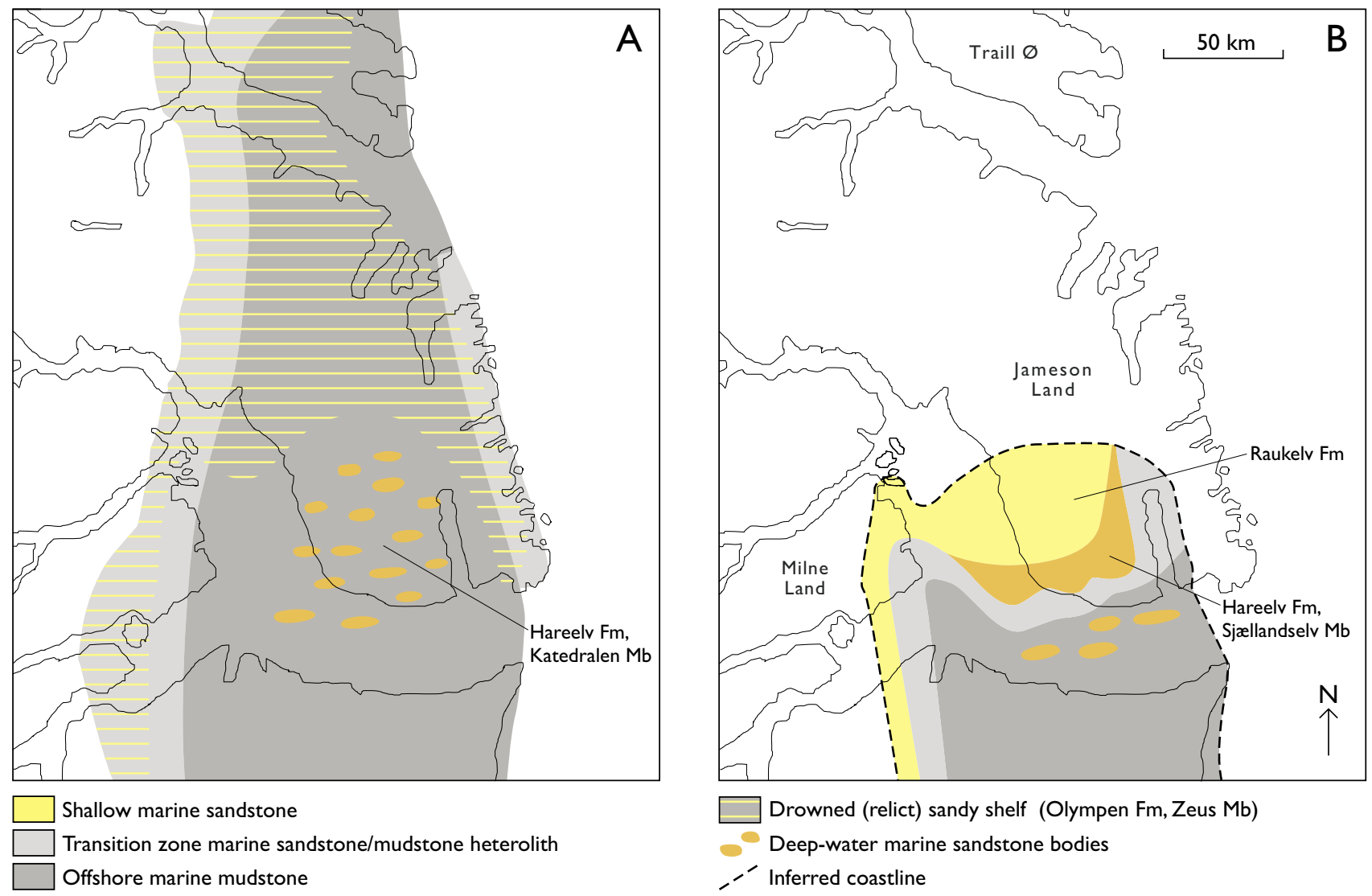

Fig. 3. Palaeogeographic reconstructions of Jameson Land and surrounding areas based on Surlyk (2003) and Bjerager et al. (2018b, this volume). The facies distribution is tentative in most areas since the distribution in the present-day offshore area is inferred and the succession has been removed by erosion in some of the present-day onshore areas.

were subsequently deposited in the Jameson Land Basin (Fig. 3) in response to a regional sea-level fall; southwards progradation of the shelf-edge clinothems of the Raukelv Formation into the basin led to repeated shelf-edge collapse and the initiation of the gravity flows (Surlyk 2003; Surlyk \& Noe-Nygaard 2005).

The provenance of the Jurassic sedimentary basins in East Greenland based on sedimentological data has been interpreted as the basement rocks of the Greenland craton, in addition to some reworking of clastic sediments (Surlyk 2003). The Devonian-Carboniferous sediments exposed north of Jameson Land during the Early Jurassic were onlapped during the Middle Jurassic and thus became less important sediment sources, but this situation may have changed during the Late Jurassic due to increased rifting and consequent exhumation and erosion of uplifted fault-block crests.

\section{Samples and methods}

Provenance analysis was performed on sandstones from six intervals in the Blokelv-1 core (Fig. 2). Five of the samples are from the Katedralen Member (sample ID 2-6) and one is from the Sjxllandselv Member (sample ID 1) of the Hareelv Formation. The sampled sandstones are structureless, grey, fine- to medium-grained, moderately to well-sorted and the grains are angular to sub-rounded (Bjerager et al. 2018a, this volume). Some of the sampled sandstones comprise high-density turbidites (sample ID $1,4)$ whereas others are injectites (sample ID 2, 3, 5, 6).

\section{Zircon U-Pb geochronology}

Samples were crushed in order to liberate the individual grains and then sieved to retrieve the fraction $<500 \mu \mathrm{m}$. Heavy-mineral concentrates were produced on a watershaking Wilfley table. Zircon grains were hand-picked 
in a random fashion to ensure that all grain sizes, shapes and colours were represented. The grains were cast into epoxy and polished to expose a central cross-section of each grain. The mount was cleaned in an ultrasonic bath with propanol, and then loaded into the sample cell of the laser ablation system for age dating. Approximately 160 grains were analysed per sample ensuring that even small age populations are detected (Vermeesch 2004).

All data were acquired with a single spot analysis on individual zircon grains using a beam diameter of $30 \mu \mathrm{m}$ and a crater depth of $c .15-20 \mu \mathrm{m}$. The amount of ablated material approximates 200-300 ng for the ablation time of $30 \mathrm{sec}$. The ablated material was analysed on an Element2 (Thermo Finnigan, Bremen) single-collector, double focusing, magnetic sector-field, inductively coupled plasma mass spectrometer (ICP-MS) with a fastfield regulator for increased scanning speed. The total acquisition time for each analysis was $60 \mathrm{sec}$., with the first $30 \mathrm{sec}$. used to measure the gas blank. The instrument was tuned to give large, stable signals for the ${ }^{206} \mathrm{~Pb}$ and ${ }^{238} \mathrm{U}$ peaks, low background count rates (typically around 150 counts per second for ${ }^{207} \mathrm{~Pb}$ ) and low oxide production rates $\left({ }^{238} \mathrm{U}^{16} \mathrm{O} /{ }^{238} \mathrm{U}\right.$ generally below $\left.2.5 \%\right)$. ${ }^{202} \mathrm{Hg},{ }^{204}(\mathrm{~Pb}+\mathrm{Hg}),{ }^{206} \mathrm{~Pb},{ }^{207} \mathrm{~Pb},{ }^{208} \mathrm{~Pb},{ }^{232} \mathrm{Th}$ and ${ }^{238} \mathrm{U}$ intensities were determined through peak jumping using electrostatic scanning in low-resolution mode and with the magnet resting at ${ }^{202} \mathrm{Hg}$. Mass ${ }^{202} \mathrm{Hg}$ was measured to monitor the ${ }^{204} \mathrm{Hg}$ interference on ${ }^{204} \mathrm{~Pb}$ where the ${ }^{202} \mathrm{Hg} /{ }^{204} \mathrm{Hg} \equiv 4.36$, which can be used to correct significant common $\mathrm{Pb}$ contributions using the model of Stacey \& Kramers (1975).

The elemental fractionation induced by the laser ablation and the instrumental mass bias on measured isotopic ratios were corrected through standard-sample bracketing using the GJ-1 zircon (Jackson et al. 2004). Long-term external reproducibility was monitored by repeated analyses of the Plešovice zircon standard (Slama et al. 2008). The analytical data are reported in an online supplementary data file. The reported ages are based on ${ }^{207} \mathrm{~Pb} /{ }^{206} \mathrm{~Pb}$ derived ages for the $>0.8 \mathrm{Ga}$ (billion years) analyses, and ${ }^{206} \mathrm{~Pb} /{ }^{238} \mathrm{U}$ ages for the $<0.8 \mathrm{Ga}$ analyses, as the latter is more precise for the younger age range. The propagation of the analytical errors follows the principles of Sambridge \& Lambert (1997). Age measurements lacking a stable ${ }^{207} \mathrm{~Pb} /{ }^{206} \mathrm{~Pb}$ plateau or with a $\mathrm{U} / \mathrm{Pb}$ or $\mathrm{Pb} /$ $\mathrm{Pb}$ error $>10 \%$ were discarded. A correction for common $\mathrm{Pb}$ was applied on up to $7 \%$ of the concordant analyses from each sample. The data are plotted using kernel density estimation (Vermeesch 2012) employing analyses that are $<10 \%$ discordant.

\section{Heavy-mineral analysis}

The grain-size interval $45-710 \mu \mathrm{m}$ was collected by sieving of crushed samples. Heavy-liquid separation utilised bromoform with a specific density of $2.82 \mathrm{~g} / \mathrm{cm} 3$, and the total heavy-mineral weight percentage (wt\%) of the chosen grain-size interval was measured. The heavy-mineral concentrates were embedded in epoxy and polished. Heavy-mineral chemistry was determined by computercontrolled scanning electron microscopy (CCSEM) at GEUS on a Philips XL40 SEM equipped with two energy dispersive X-ray (EDX) detectors: a Thermo Nanotrace and a Pioneer Voyager detector (Keulen et al. 2008, 2012). Approximately 1200 grains were analysed in each sample, of which between 22 and 327 grains were used in the mineral statistics. This is because the heavymineral samples contain mica minerals and authigenic heavy minerals, which were excluded from the heavymineral suite results due to their dependency on depositional environment and diagenesis. As there is a large compositional overlap between the minerals amphibole, pyroxene and tourmaline in standard-less EDX analyses, these have been combined into one group in this study, labelled mafic minerals. The group of other heavy minerals includes ilmenite, corundum, monazite and xenotime, each of which is present in amounts $<5 \%$.

\section{Results}

The zircon $\mathrm{U}-\mathrm{Pb}$ age data can be found in the online supplementary material. The age data are displayed using kernel-density estimation (Fig. 4) and cumulative age distribution (Fig. 5). The zircon ages cover a broad Archaean to Palaeozoic age span, but with the dominant zircon $\mathrm{U}-\mathrm{Pb}$ ages occurring between 2.0 and $1.0 \mathrm{Ga}$ (Fig. 4). Eight peak ages are present when combining all data: $2.71,2.49,1.95,1.65,1.49,1.37,1.10$ and $0.43 \mathrm{Ga}$.

The relative proportion between the ages in each sample is illustrated by dividing the data into six age intervals (Table 1). The grains older than 2.2 Ga comprise 12 $23 \%$ of each sample, whereas grains with ages of 2.2-1.8 Ga constitute 6-23\%. Pronounced peak ages are present within each of the 1.8-1.6, 1.6-1.3 and 1.3-0.8 Ga age intervals, which cover 17-25, 14-22 and $18-34 \%$ of the measured ages, respectively (Table 1 ). The youngest age interval of $0.6-0.3 \mathrm{Ga}$ is present in small proportions of $0-3 \%$ in the samples.

The shallowest sample (sample ID 1) is the only sample that does not have an age peak at 1.66-1.64 Ga, which is pronounced in the other samples (Fig. 4). The 
Table 1. Distribution in six age intervals of the analysed zircon grains with concordant ages

\begin{tabular}{c|c|c|c|c|c|c|c}
\hline $\begin{array}{c}\text { Age interval } \\
(\mathrm{Ga})\end{array}$ & Min. age & 0.3 & 0.8 & 1.3 & 1.6 & 1.8 & 2.2 \\
\hline \multirow{4}{*}{$\begin{array}{c}\text { Max. age } \\
\text { Number of }\end{array}$} & 0.6 & 1.3 & 1.6 & 1.8 & 2.2 & 3.8 \\
\hline $\begin{array}{c}\text { zircon grains } \\
(\%)\end{array}$ & $43.16 \mathrm{~m}$ ID $~$ & 2 & 27 & 20 & 17 & 12 & 23 \\
& $69.78 \mathrm{~m}$ ID 3 & 0 & 34 & 17 & 24 & 6 & 19 \\
& $139.27 \mathrm{~m}$ ID 4 & 3 & 31 & 18 & 20 & 16 & 12 \\
& $181.53 \mathrm{~m}$ ID 5 & 3 & 24 & 14 & 18 & 23 & 18 \\
& $221.18 \mathrm{~m}$ ID 6 & 2 & 18 & 17 & 25 & 20 & 18 \\
\hline
\end{tabular}

cumulative age distributions show that no significant difference exists between the six measured age distributions since the distance between the curves is small (Fig. 5).
Kolmogorov-Smirnov (K-S) tests (Guynn \& Gehrels 2010) were performed on the zircon age data to determine if the samples were derived from different sources by comparing the distance between the cumulative agedistribution curves (Fig. 5). Two samples are regarded as significantly dissimilar if they have a P-value $<0.05$ and they will then probably have different provenance. The results show that all P-values are $>0.05$ (Table 2). It is therefore unlikely that the samples came from different parent populations at a $95 \%$ confidence level. The samples ID 2-4 resemble each other well according to the high P-values of 0.99. The sample ID 5 shows good resemblance to the samples ID 1 and ID 6 (P-values of 0.97 and 0.91 , respectively).

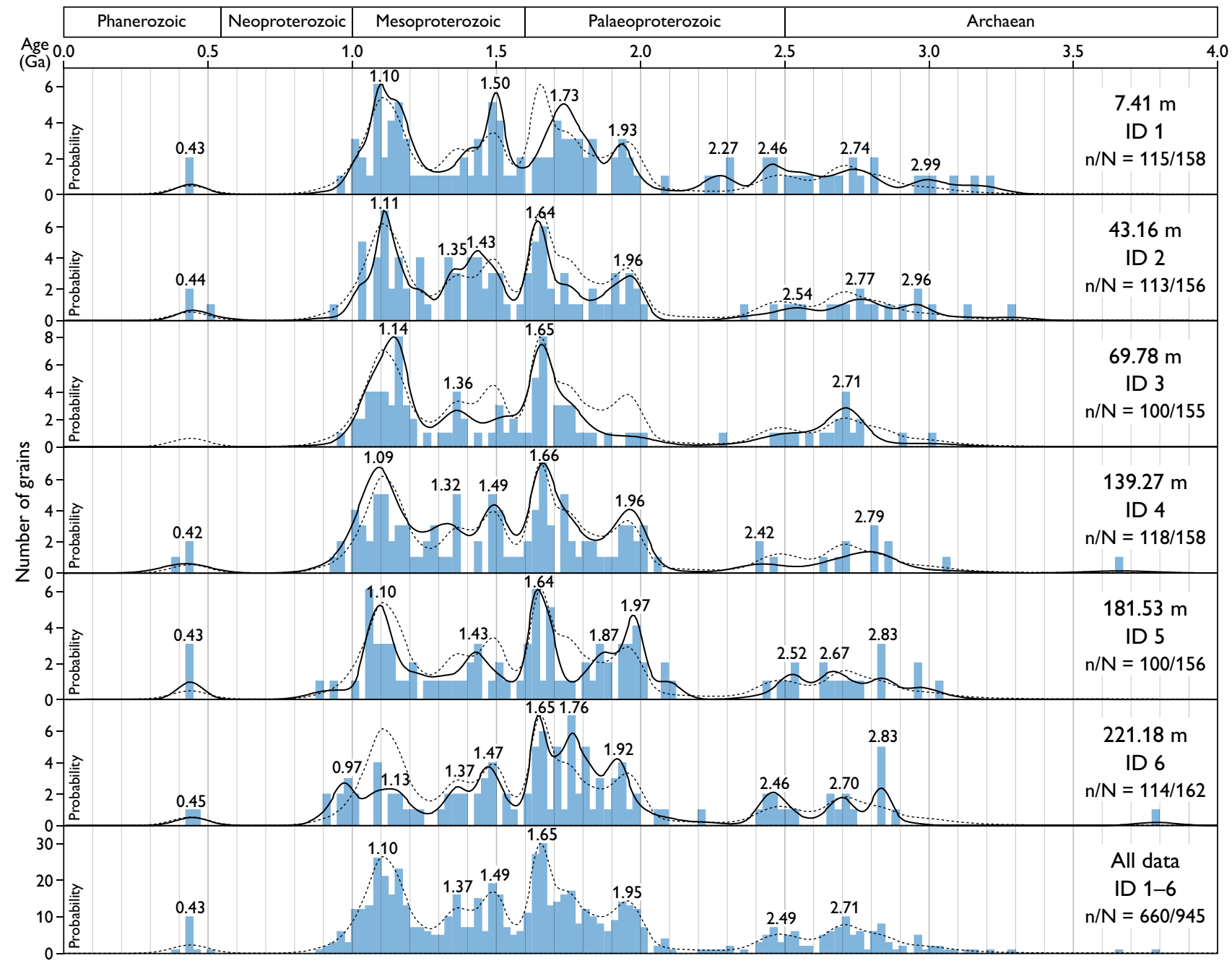

Fig. 4. Zircon U-Pb ages of the Hareelv Formation. The ages are plotted with a black line and annotated peak ages using kernel density estimation (Vermeesch 2012) and histograms with a $25 \mathrm{Myr}$ bin interval. Only zircon ages with $<10 \%$ discordance are plotted, which is signified by "n/N" (the number of concordant analyses out of the total number of analyses). The lowermost panel shows the distribution of all zircon ages from the six samples, and this dotted line is shown on all samples for comparison. 
Table 2. P-values of the K-S test of the zircon age data

\begin{tabular}{rl|llllll}
\hline & & ID 1 & ID 2 & ID 3 & ID 4 & ID 5 & ID 6 \\
\hline $7.41 \mathrm{~m}$ & ID 1 & & 0.447 & 0.382 & 0.477 & 0.966 & 0.476 \\
$43.16 \mathrm{~m}$ & ID 2 & 0.447 & & 0.993 & 0.992 & 0.477 & 0.093 \\
$69.78 \mathrm{~m}$ & ID 3 & 0.382 & 0.993 & & 0.880 & 0.194 & 0.080 \\
$139.27 \mathrm{~m}$ & ID 4 & 0.477 & 0.992 & 0.880 & & 0.301 & 0.122 \\
$181.53 \mathrm{~m}$ & ID 5 & 0.966 & 0.477 & 0.194 & 0.301 & & 0.909 \\
$221.18 \mathrm{~m}$ & ID 6 & 0.476 & 0.093 & 0.080 & 0.122 & 0.909 & \\
\hline
\end{tabular}

The heavy-mineral assemblage consists, in decreasing order of abundance, of rutile, mafic minerals, zircon, leucoxene, garnet, apatite, epidote, olivine and small amounts of other minerals (Fig. 6). The garnets are classified as almandine and generally contain more $\mathrm{Mg}$ than $\mathrm{Ca}$. When including mica minerals in the heavy-mineral assemblage, they constitute $60-91 \%$ of the mineral grains. Muscovite comprises $72-98 \%$ of the mica minerals. The heavy-mineral content is largest in the uppermost sample (Table 3).

\section{Discussion}

The age distribution of all analysed zircon grains from the Hareelv Formation is shown in Fig. 7A, and selected published zircon age data from older rocks in the area are shown in Figs $7 \mathrm{~B}-\mathrm{H}$ for comparison.

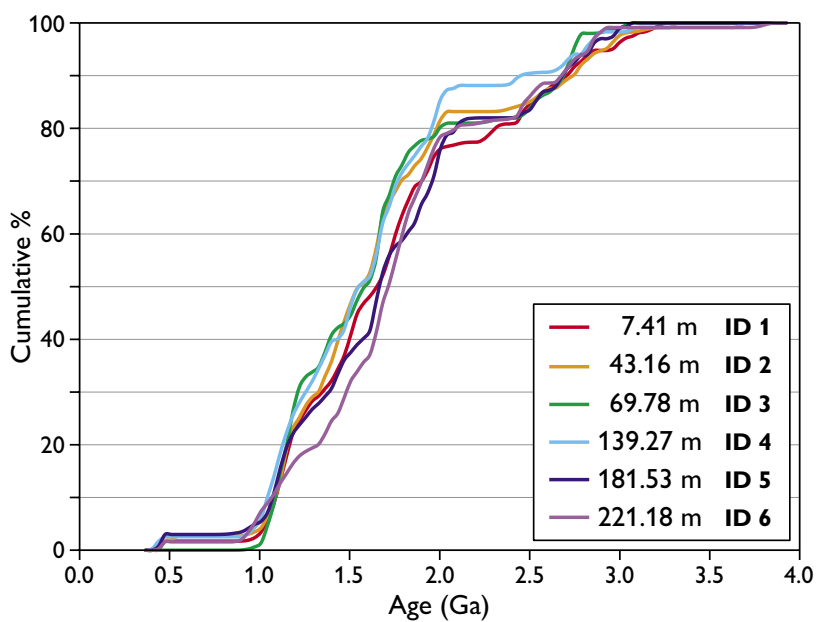

Fig. 5. Cumulative age distributions of zircons from the Hareelv Formation.
Table 3. Grain size and heavy-mineral content of the analysed sandstones

\begin{tabular}{r|rcc|cc}
\hline & \multicolumn{3}{|c|}{$\begin{array}{c}\text { Grain size } \\
\text { of sandstones (wt\%) }\end{array}$} & \multicolumn{2}{c}{$\begin{array}{c}\text { Heavy-mineral } \\
\text { content (wt\%) }\end{array}$} \\
& $<45 \mu \mathrm{m}$ & $45-710 \mu \mathrm{m}$ & $>710 \mu \mathrm{m}$ & $45-710 \mu \mathrm{m}$ & Total \\
\hline $7.41 \mathrm{~m}$ ID 1 & 5.3 & 23.3 & 71.4 & 4.74 & 1.10 \\
43.16 m ID 2 & 18.5 & 81.0 & 0.5 & 0.94 & 0.76 \\
69.78 m ID 3 & 10.8 & 89.2 & 0.0 & 0.87 & 0.77 \\
139.27 m ID 4 & 6.9 & 50.6 & 42.4 & 0.47 & 0.24 \\
181.53 m ID 5 & 5.4 & 37.5 & 57.1 & 1.21 & 0.45 \\
221.18 m ID 6 & 6.2 & 30.9 & 62.9 & 1.50 & 0.46 \\
\hline
\end{tabular}

\section{Basement and metasediment signal}

The dominant zircon age populations present in the crystalline basement complexes of East Greenland (Fig. 1) have age ranges of about $2.8-2.5$ and $2.0-1.8 \mathrm{Ga}$ (Fig. $7 \mathrm{H}$; Thrane 2002). These Archaean and Palaeoproterozoic rocks are primarily orthogneisses of granitic to tonalitic composition, and their heavy-mineral assemblages are therefore dominated by mafic minerals and mica minerals. The metasedimentary rocks of the Krummedal supracrustal sequence (Fig. 1) mainly have zircon ages of 1.8-1.0 Ga (Fig. 7G; Watt et al. 2000; Leslie \& Nutman 2003). They consist primarily of pelitic and psammitic metasediments that underwent intermediate to highgrade metamorphism, resulting in a heavy-mineral assemblage dominated by mica minerals and garnet with localised sillimanite (Watt \& Thrane 2001; Leslie \& Nutman 2003).

The zircon ages of the Archaean and Palaeoproterozoic basement complexes in East Greenland correspond largely to two of the oldest age populations recorded in the Hareelv Formation with peak ages of 2.71 and 1.95 $\mathrm{Ga}$ (Fig. 7). However, the latest Archaean to earliest Palaeoproterozoic ages in the Hareelv Formation with a peak age of $2.49 \mathrm{Ga}$ are not comparable to ages reported by Thrane (2002) from the basement complexes west of Kong Oscar Fjord (Fig. 1); such ages may therefore be present in other areas of the complexes.

The ages of the Krummedal supracrustal sequence concur with the late Palaeoproterozoic and the Mesoproterozoic age populations in the Hareelv Formation with peak ages of 1.65, 1.49 and $1.10 \mathrm{Ga}$ (Fig. 7). The Mesoproterozoic age population with peak age of 1.37 Ga in the Hareelv Formation is only pronounced in some of the samples (Fig. 4), and the population is not evident in the Krummedal supracrustal sequence (Fig. 7). The late Palaeoproterozoic and late Mesoproterozoic age populations are dominant both in the Hareelv Formation and in the Krummedal supracrustal sequence. However, 

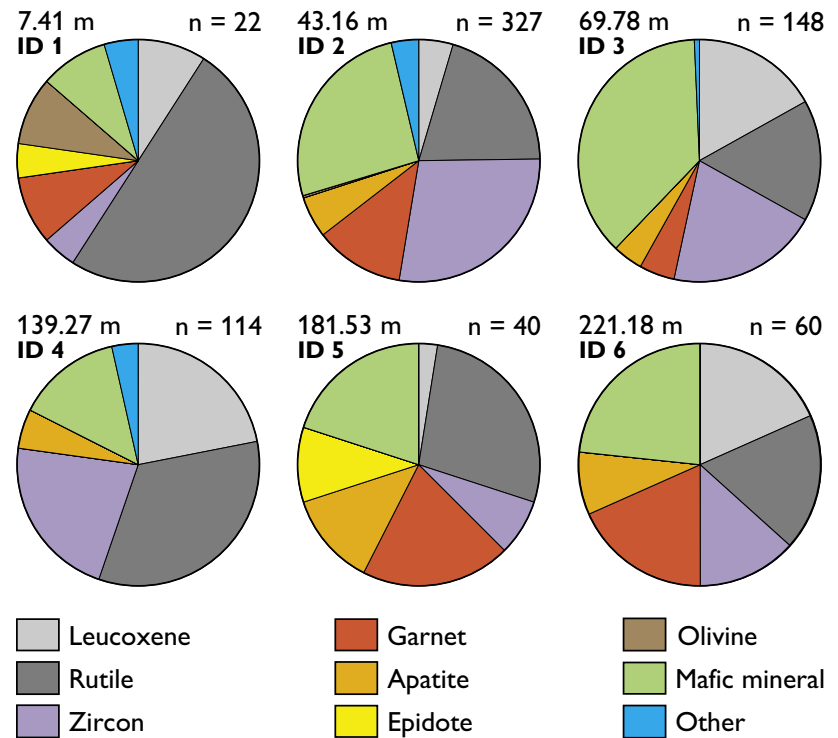

Fig. 6. Heavy-mineral contents of the Hareelv Formation excluding mica minerals and authigenic heavy minerals. The number of employed analyses (out of the total number of analyses of $c .1200$ per sample) is indicated by ' $n$ '.

the metamorphic rocks of the East Greenland Caledonides comprise a complex series of lithologies and the Krummedal supracrustal sequence is not representative for them all.

The ages of the Caledonian granites that formed between 466 and $423 \mathrm{Ma}$ in East Greenland (Leslie \& Nutman 2003; Kalsbeek et al. 2008a; Rehnström 2010) are in agreement with the minor age population with a peak age of $0.43 \mathrm{Ga}$ present in five of the samples from the Hareelv Formation (Fig. 4).

The high contents of $\mathrm{Fe}$ and $\mathrm{Mg}$ in the garnets in the Hareelv Formation suggest an origin from a felsic $\mathrm{Al}$-rich rock type that has been subjected to intermediate to high metamorphic conditions. The presence of zircon, rutile, leucoxene and apatite (Fig. 6) is also consistent with derivation from felsic source rocks such as granites and granitic gneisses.

The proportion of mafic minerals relative to the remaining heavy minerals is smaller in the Hareelv Formation than in the probable crystalline and metasedimentary source rocks in the East Greenland Caledonides. This may be indicative of several cycles of sedimentation prior to deposition in the Jameson Land Basin since mafic minerals break down easily during weathering and transport (Morton \& Hallsworth 1999). Furthermore, amphibole and sillimanite largely dissolve during the first $3 \mathrm{~km}$ of burial (Andò et al. 2012) and the studied Hareelv Formation was buried to about $2.8 \mathrm{~km}$ prior to Cenozoic uplift (Green \& Japsen 2018, this volume). Hence, the proportions of the mechanically and chemically stable heavy minerals, such as zircon and rutile, are high compared to the other heavy minerals in the Hareelv Formation (Fig. 6). The negligible amount of ilmenite in the heavy-mineral suite of the sandstones probably indicates that leucoxene formed at the expense of ilmenite (Weibel 2003).

The interpretation of the non-mica heavy-mineral assemblage reported in Fig. 6 is based on rather few grains because of the high content of mica minerals and authigenic heavy minerals (ankerite and pyrite) in the samples, so the variations in the relative proportions between the heavy minerals are not significant. It should be noted, however, that a similar suite of heavy minerals is present in all the samples (Fig. 6). The provenance signal of the two finest-grained samples (ID 2, 3; Table 3) shows no significant deviation from the remaining samples (Tables 1,2 , Figs 4-6) so it is not influenced by grain size. The number of grains $>710 \mu \mathrm{m}$ in size is overestimated (Table 3) since it was not possible to disintegrate all individual grains during crushing of the samples.

\section{Reworking of older sediments}

Zircon age data from the Neoproterozoic Eleonore Bay Supergroup, including the Nathorst Land Group and the Lyell Land Group, have peak ages of 1.75 and $1.05 \mathrm{Ga}$, respectively (Fig. 7; Dhuime et al. 2007; Slama et al. 2011). These ages are not prominent in the Hareelv Formation, so only a minor amount of sediment can have been reworked from this part of the Eleonore Bay Supergroup into the Jameson Land Basin during the Late Jurassic. However, it should be noted that the seven samples from the Eleonore Bay Supergroup are not considered representative of the entire $14 \mathrm{~km}$ thick succession.

Devonian and Carboniferous sediments in the Kong Oscar Fjord area (Fig. 1) have a wide range of age populations (Slama et al. 2011) that resemble those in the Hareelv Formation (Fig. 7). The relative dominance of the various age peaks, however, is not similar for the different sediments (this study and Slama et al. 2011): the Devonian sediments contain fewer Archaean ages and more early Neoproterozoic and Palaeozoic ages than the Hareelv Formation, whereas the Carboniferous sediments contain fewer middle Palaeoproterozoic ages and more Palaeozoic ages than the studied sandstones. However, some degree of modification of the provenance signal 


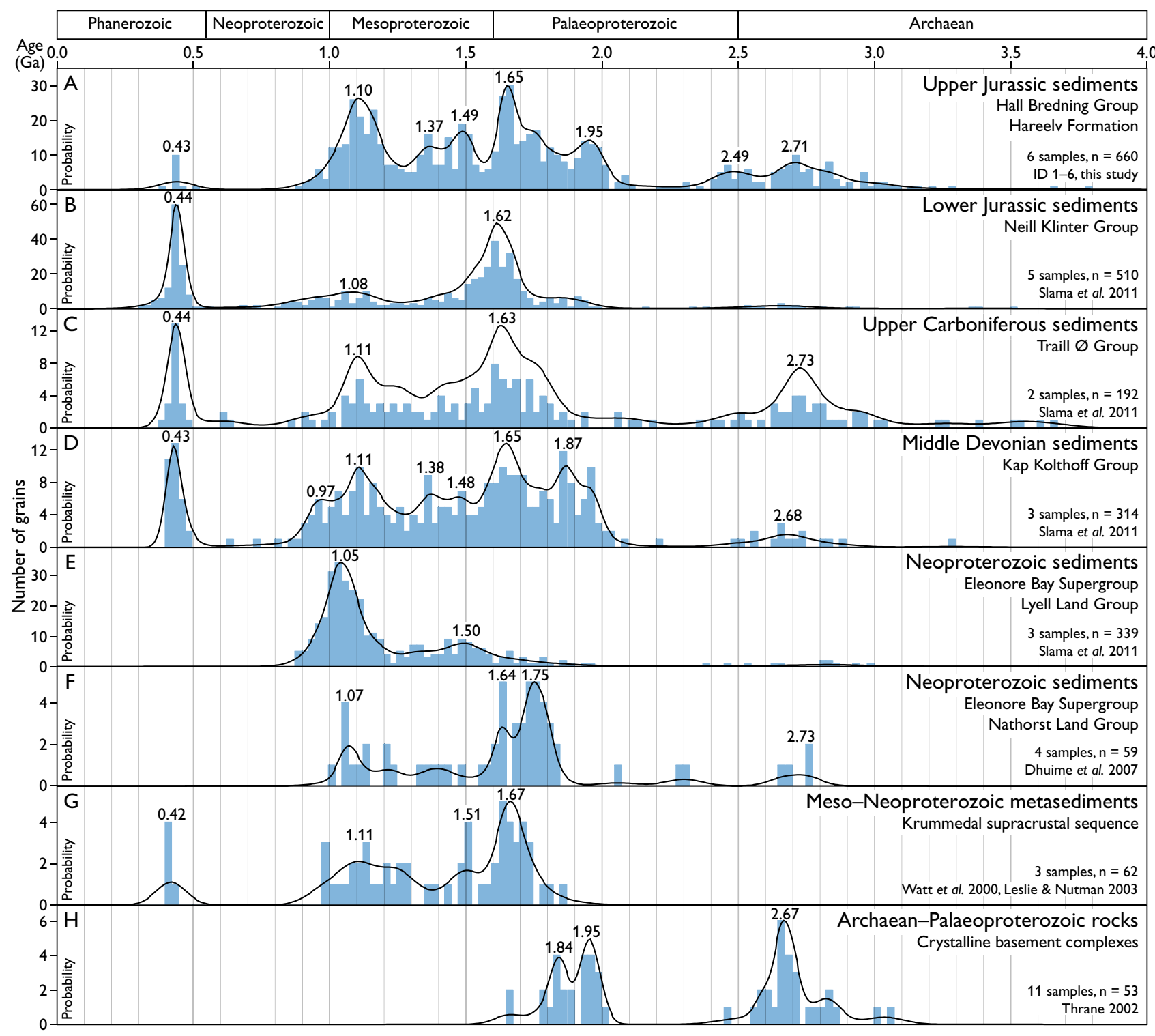

Fig. 7. Zircon U-Pb ages of the analysed Upper Jurassic sandstones (A) compared to older sediments and basement complexes (B-H; Watt $e$ t al. 2000; Thrane 2002; Leslie \& Nutman 2003; Dhuime et al. 2007; Slama et al. 2011). Ages with <10\% discordance are employed and they are plotted using kernel density estimation (Vermeesch 2012). The locations of the samples are shown in Fig. 1.

is likely to have occurred during erosion and transport. Furthermore, the paucity of the database that provides the comparison should be taken into account; the $8 \mathrm{~km}$ thick Devonian succession is covered by only three samples and the $2 \mathrm{~km}$ thick Carboniferous succession is represented by two samples.

Thus, the Hareelv Formation may have been sourced by reworking of Devonian and/or Carboniferous sediments into the Jameson Land Basin. Ultimately, all the sediments originate from the same areas in the Caledo- nides, which must comprise a combination of the Archaean-Palaeoproterozoic crystalline complexes (with their late Archaean to middle Palaeoproterozoic zircon age spectrum), the Meso-Neoproterozoic metasediments (with their late Palaeoproterozoic to late Mesoproterozoic zircon age spectrum) and the intruded Caledonian granites (Fig. 7). These units are closely interrelated in the present-day exposed part of the East Greenland Caledonides (Fig. 1), where a thick section of the Krummedal supracrustal sequence must have been eroded to ex- 
pose the underlying crystalline basement (Higgins et al. 2004).

The Liverpool Land High was uplifted during the Early Jurassic and supplied sediment to the Jameson Land Basin (Surlyk 2003). The dominant age populations with peak ages of 1.62 and $0.44 \mathrm{Ga}$ found in Lower Jurassic sediments in the eastern Jameson Land Basin (Fig. 7; Slama et al. 2011) correspond to ages present in Liverpool Land in the Eclogite Terrane and in Caledonian granitoid rocks, respectively (Augland et al. 2011, 2012). This distinctive age signature is not present in the Hareelv Formation, so the latter cannot have received material from Liverpool Land or its derived sediments. This is in accordance with the gradual Jurassic onlap onto Liverpool Land (Surlyk 2003) indicating that it was no longer a source area in Late Jurassic times.

\section{Sediment transport}

It is plausible that the sediments in the Hareelv Formation and the associated shelf-edge systems were derived partly or fully from reworking of Palaeozoic sediments, as described above. In that case, a contribution may have come from immediately north-west of the basin, where Carboniferous sediments are exposed today (Fig. 1), and/ or from farther south where these strata were probably outcropping in Jurassic times. The Paleozoic sediments were onlapped during the Middle Jurassic, but increased faulting associated with the rifting that began in the Middle Jurassic is known to have led to local erosion of fault crests during the Late Jurassic (Surlyk 2003). Such faulting may also have occurred inland (west) of the Jameson Land Basin, thereby resulting in reworking of Palaeozoic sediments.

Small differences exist between the zircon age distributions of the Hareelv Formation (Table 1; Fig. 5), but none of the analysed samples was found to be statistically dissimilar according to the performed K-S tests (Table 2). This suggests a consistent and persistent transport path for the sands deposited in this part of the Jameson Land Basin in the Late Jurassic.

The results of the provenance analysis of the Hareelv Formation may also be used to characterise the shelfedge sediments that collapsed and subsequently were redeposited by gravity flows (Fig. 3). The feeding shelfedge sands are represented by the proximal facies of the Olympen Formation (or younger equivalents) during deposition of the Katedralen Member and subsequently by the Raukelv Formation during deposition of the Sjæl- landselv Member (Surlyk 2003; Surlyk et al. 2007; Bjerager et al. 2018b, this volume). The Olympen Formation (Zeus Member) and the Raukelv Formation (Fig. 2) are both interpreted to have been deposited during relative lowstands in the region, but the source terranes that supplied sediment to the northern shelf edge of the Jameson Land Basin may not have been entirely the same during these two time intervals since there are some distinctive differences between the samples from the Katedralen and Sjællandselv Members. The sandstone from the Sjællandselv Member (ID 1) has a higher heavy-mineral content (Table 3) and a higher proportion of Archaean zircon grains (Table 1) than the sandstones from the Katedralen Member (ID 2-6). The Sjællandselv Member sample has a peak age at $1.73 \mathrm{Ga}$, but lacks the pronounced peak age at $1.66-1.64 \mathrm{Ga}$ in the remaining samples (Fig. 4), and sandstones from the Sjællandselv Member are coarsergrained than the Katedralen Member sandstones (Surlyk 2003; Bjerager et al. 2018a, this volume). Furthermore, the Sjællandselv Member sample contains 4\% rock fragments compared to only $0-1 \%$ in the samples from the Katedralen Member (Olivarius et al. 2018, this volume). This could indicate rejuvenation of the topography during the Volgian such that the Raukelv Formation received some of its sediment from more proximal sources in comparison to the previous shelf-edge sands. This is in accordance with the Late Jurassic rifting that caused block faulting and thereby created local sediment sources through erosion of tilted footwall crests (Surlyk 2003).

\section{Conclusions}

The large range of zircon $\mathrm{U}-\mathrm{Pb}$ ages in the Upper Jurassic Hareelv Formation resembles the zircon age spectrum in the Caledonides of East and North-East Greenland. The heavy-mineral suite and garnet composition in the sandstones indicate derivation from felsic rocks. Archaean-Palaeoproterozoic crystalline complexes, MesoNeoproterozoic metamorphic rocks and Caledonian migmatites and granites are considered to represent the original source of the material.

Some or all of the material may, however, have undergone several sediment cycles before deposition in the Jameson Land Basin in the Late Jurassic. Sediment supply to the Hareelv Formation from reworking of Devonian and Carboniferous sediments is plausible since the preserved parts of these successions contain corresponding age populations. However, it should be emphasised that the database for comparison is limited. 
The provenance signature is a reflection of the area exposed to lowstand erosion during the accumulation of the southwards prograding shelf-edge deltas that subsequently fed the gravity flows of the Hareelv Formation. The provenance signature is rather uniform in the $\mathrm{Ox}$ fordian-Kimmeridgian Katedralen Member, but there are a number of indications of a shorter sediment transport distance for the sands of the early Volgian Sjxllandselv Member, potentially reflecting rejuvenation of the topography during rifting.

Supplementary data to this article can be found online at: www.geus.dk/Bulletin 42

\section{Acknowledgements}

John Boserup, Anders Pilgaard, Fiorella F. Aguilera, Mojagan Alaei, Jørgen Kystol and Ingerlise Nørgaard are thanked for sampling and analysis. Dirk Frei, Niels Henriksen, Kristine Thrane and Peter Appel provided valuable advice and Jette Halskov kindly did the artwork. The referees, Jiri Slama and Martin Sønderholm, are thanked for insightful comments that significantly improved the manuscript.

\section{References}

Andò, S., Garzanti, E., Padoan, M. \& Limonta, M. 2012: Corrosion of heavy minerals during weathering and diagenesis: A catalog for optical analysis. Sedimentary Geology 280, 165-178.

Augland, L.E., Andresen, A. \& Corfu, F. 2011: Terrane transfer during the Caledonian orogeny: Baltican affinities of the Liverpool Land Eclogite Terrane in East Greenland. Journal of the Geological Society (London) 168, 15-26.

Augland, L.E., Andresen, A., Corfu, F. \& Daviknes, H.K. 2012: Late Ordovician to Silurian ensialic magmatism in Liverpool Land, East Greenland: new evidence extending the northeastern branch of the continental Laurentian magmatic arc. Geological Magazine 149, 561-577.

Bjerager, M., Alsen, P., Bojesen-Koefoed, J.A., Piasecki, S. \& Pilgaard, A. 2018b: Late Jurassic evolution of the Jameson Land Basin, East Greenland - implications of the Blokelv-1 borehole. In: Ineson, J. \& Bojesen-Koefoed, J.A. (eds): Petroleum geology of the Upper Jurassic - Lower Cretaceous of East and North-East Greenland: Blokelv-1 borehole, Jameson Land Basin. Geological Survey of Denmark and Greenland Bulletin 42, 149-168 (this volume).

Bjerager, M., Kjøller, C., Olivarius, M. \& Schovsbo, N.M. 2018a: Sedimentology, geochemistry and reservoir properties of Upper Jurassic deep marine sediments (Hareelev Formation) in the Blokelv-1 borehole, Jameson Land Basin, East Greenland. In: Ineson, J. \&
Bojesen-Koefoed, J.A. (eds): Petroleum geology of the Upper Jurassic - Lower Cretaceous of East and North-East Greenland: Blokelv-1 borehole, Jameson Land Basin. Geological Survey of Denmark and Greenland Bulletin 42, 39-64 (this volume).

Brooks, C.K. 2011: The East Greenland rifted volcanic margin. Geological Survey of Denmark and Greenland Bulletin 24, 96 pp.

Dhuime, B., Bosch, D., Bruguier, O., Caby, R. \& Pourtales, S. 2007:

Age, provenance and post-deposition metamorphic overprint of detrital zircons from the Nathorst Land group (NE Greenland) - A LA-ICP-MS and SIMS study. Precambrian Research 155 , 24-46.

Green, P.F \& Japsen, P. 2018: Burial and exhumation history of the Jameson Land Basin, East Greenland, estimated from thermochronological data from the Blokelv-1 core. In: Ineson, J. \& BojesenKoefoed, J.A. (eds): Petroleum geology of the Upper Jurassic Lower Cretaceous of East and North-East Greenland: Blokelv-1 borehole, Jameson Land Basin. Geological Survey of Denmark and Greenland Bulletin 42, 133-147 (this volume).

Guynn, J. \& Gehrels, G. 2010: Comparison of detrital zircon age distributions using the K-S test. Arizona LaserChron Center, University of Arizona, Tucson, $16 \mathrm{pp}$.

Henriksen, N., Higgins, A.K., Gilotti, J.A. \& Smith, M.P. 2008: Introduction - The Caledonides of Greenland. In: Higgins, A.K., Gilotti, J.A. \& Smith, M.P. (eds): The Greenland Caledonides: Evolution of the northeast margin of Laurentia. The Geological Society of America, Memoir 202, v-xv.

Higgins, A.K. et al. 2004: The foreland-propagating thrust architecture of the East Greenland Caledonides $72^{\circ}-75^{\circ} \mathrm{N}$. Journal of the Geological Society (London) 161, 1009-1026.

Higgins, A.K. \& Leslie, A.G. 2008: Architecture and evolution of the East Greenland Caledonides -An introduction. In: Higgins, A.K., Gilotti, J.A. \& Smith, M.P. (eds): The Greenland Caledonides: Evolution of the northeast margin of Laurentia. Geological Society of America Memoir 202, 29-53.

Jackson, S.E., Pearson, N.J., Griffin, W.L. \& Belousova, E.A. 2004: The application of laser ablation-inductively coupled plasma-mass spectrometry to in situ $\mathrm{U}-\mathrm{Pb}$ zircon geochronology. Chemical Geology 211, 47-69.

Kalsbeek, F., Thrane, K., Nutman, A.P. \& Jepsen, H.F. 2000: Late Mesoproterozoic to early Neoproterozoic history of the East Greenland Caledonides: evidence for Grenvillian orogenesis? Journal of the Geological Society (London) 157, 1215-1225.

Kalsbeek, F., Jepsen, H.F. \& Nutman, A.P. 2001: From source migmatites to plutons: tracking the origin of ca. $435 \mathrm{MaS}$-type granites in the East Greenland Caledonian orogen. Lithos 57, 1-21.

Kalsbeek, F., Higgins, A.K., Jepsen, H.F., Frei, R. \& Nutman, A.P. 2008a: Granites and granites in the East Greenland Caledonides. In: Higgins, A.K., Gilotti, J.A. \& Smith, M.P. (eds): The Greenland Caledonides: Evolution of the northeast margin of Laurentia. Geological Society of America Memoir 202, 227-249.

Kalsbeek, F., Thrane, K., Higgins, A.K., Jepsen, H.F., Leslie, A.G., Nutman, A.P. \& Frei, R. 2008b: Polyorogenic history of the East Greenland Caledonides. In: Higgins, A.K., Gilotti, J.A. \& Smith, M.P. (eds): The Greenland Caledonides: Evolution of the northeast margin of Laurentia. Geological Society of America Memoir 202, 55-72. 
Keulen, N., Frei, D., Bernstein, S., Hutchison, M.T., Knudsen, C. \& Jensen, L. 2008: Fully automated analysis of grain chemistry, size and morphology by CCSEM: examples from cement production and diamond exploration. Geological Survey of Denmark and Greenland Bulletin 15, 93-96.

Keulen, N., Frei, D., Riisager, P. \& Knudsen, C. 2012: Analysis of heavy minerals in sediments by Computer-Controlled Scanning Electron Microscopy (CCSEM): principles and applications. Mineralogical Association Canada, Short Course, 42, 167-184.

Larsen, M. \& Surlyk, F. 2003: A shelf-edge delta and slope system of the upper Callovian-middle Oxfordian Olympen Formation, East Greenland. In: Ineson, J.R. \& Surlyk, F. (eds): The Jurassic of Denmark and Greenland. Geological Survey of Denmark and Greenland Bulletin 1, 893-930.

Larsen, P.-H., Olsen, H. \& Clack, J.A. 2008: The Devonian basin in East Greenland - Review of basin evolution and vertebrate assemblages. In: Higgins, A.K., Gilotti, J.A. \& Smith, M.P. (eds): The Greenland Caledonides: Evolution of the northeast margin of Laurentia. Geological Society of America Memoir 202, 273-292.

Leslie, A.G. \& Nutman, A.P. 2003: Evidence for Neoproterozoic orogenesis and early high temperature Scandian deformation events in the southern East Greenland Caledonides. Geological Magazine 140, 309-333.

McKerrow, W.S., Mac Niocaill, C. \& Dewey, J.F. 2000: The Caledonian Orogeny redefined. Journal of the Geological Society (London) 157, 1149-1154.

Morton, A.C. \& Hallsworth, C.R. 1999: Processes controlling the composition of heavy mineral assemblages in sandstones. Sedimentary Geology 124, 3-29.

Olivarius, M., Weibel, R., Schovsbo, N.H., Olsen, D. \& Kjøller, C. 2018: Diagenesis of Upper Jurassic sandstones of the Blokelv-1 core in the Jameson Land Basin, East Greenland. In: Ineson, J. \& Bojesen-Koefoed, J.A. (eds): Petroleum geology of the Upper Jurassic - Lower Cretaceous of East and North-East Greenland: Blokelv-1 borehole, Jameson Land Basin. Geological Survey of Denmark and Greenland Bulletin 42, 65-84 (this volume).

Rehnström, E.F. 2010: Prolonged Paleozoic magmatism in the East Greenland Caledonides: Some constraints from $\mathrm{U}-\mathrm{Pb}$ ages and $\mathrm{Hf}$ isotopes. The Journal of Geology 118, 447-465.

Sambridge, M. \& Lambert, D.D. 1997: Propagating errors in decay equations: Examples from the Re-Os isotopic system. Geochimica et Cosmochimica Acta 61, 3019-3024.

Slama, J. et al. 2008: Plešovice zircon - a new natural reference material for $\mathrm{U}-\mathrm{Pb}$ and $\mathrm{Hf}$ isotopic microanalysis. Chemical Geology 249, 1-35.

Slama, J., Walderhaug, O., Fonneland, H., Kosler, J. \& Pedersen, R.B. 2011: Provenance of Neoproterozoic to upper Cretaceous sedimentary rocks, eastern Greenland: Implications for recognizing the sources of sediments in the Norwegian Sea. Sedimentary Geo$\operatorname{logy} 238,254-267$.

Stacey, J.S. \& Kramers, J.D. 1975: Approximation of terrestrial lead isotope evolution by a two-stage model. Earth and Planetary Science Letters 26, 207-221.

Stemmerik, L., Christensen, F.G., Piasecki, S., Jordt, B., Marcussen, C. \& Nøhr-Hansen, H. 1992: Depositional history and petroleum geology of the Carboniferous to Cretaceous sediments in the northern part of East Greenland. Norwegian Petroleum Federation, Special Publication 2, 67-87.

Stemmerik, L., Clausen, O.R., Korstgård, J., Larsen, M., Piasecki, S., Seidler, L., Surlyk, F. \& Therkelsen, J. 1997: Petroleum geological investigations in East Greenland: project 'Resources of the sedimentary basins of North and East Greenland'. Geology of Greenland Survey Bulletin 176, 29-38.

Surlyk, F. 2003: The Jurassic of East Greenland: a sedimentary record of thermal subsidence, onset and culmination of rifting. In: Ineson, J.R. \& Surlyk, F. (eds): The Jurassic of Denmark and Greenland. Geological Survey of Denmark and Greenland Bulletin 1, 659722.

Surlyk, F. \& Noe-Nygaard, N. 2005: A forced regressive shelf-margin wedge formed by transition-slope progradation: lowermost Cretaceous Rauk Plateau Member, Jameson Land, East Greenland. Bulletin of the Geological Society of Denmark 52, 227-243.

Surlyk, F., Gjelberg, J. \& Noe-Nygaard, N. 2007: The Upper Jurassic Hareelv Formation of East Greenland: A giant sedimentary injection complex. In: Hurst, A. \& Cartwright, J. (eds): Sand injectites: Implications for hydrocarbon exploration and production. AAPG Memoir 87, 141-149.

Thrane, K. 2002: Relationships between Archaean and Palaeoproterozoic crystalline basement complexes in the southern part of the East Greenland Caledonides: an ion microprobe study. Precambrian Research 113, 19-42.

Vermeesch, P. 2004: How many grains are needed for a provenance study? Earth and Planetary Science Letters 224, 441-451.

Vermeesch, P. 2012: On the visualisation of detrital age distributions. Chemical Geology 312-313, 190-194.

Watt, G.R., Kinny, P.D \& Friderichsen, J.D. 2000: U-Pb geochronology of Neoproterozoic and Caledonian tectonothermal events in the East Greenland Caledonides. Journal of the Geological Society (London) 157, 1031-1048.

Watt, G.R. \& Thrane, K. 2001: Early Neoproterozoic events in East Greenland. Precambrian Research 110, 165-184.

Weibel, R. 2003: Alteration of detrital Fe-Ti oxides in Miocene fluvial deposits, central Jutland, Denmark. Bulletin of the Geological Society of Denmark 50, 171-183. 